\title{
Survei Bibliografis Kajian al-Qur'ān dan Tafsīir di Barat: Kajian Publikasi Buku dalam Bahasa Inggris Sejak Tahun 2000an
}

\author{
Yusuf Rahman ${ }^{1}$
}

\begin{abstract}
This articel surveys the works of Western scholars on the Qur'an and tafsir in the present years. These works are not only authored by non Muslim scholars but also Muslim scholars. Some of them are affiliated with the radical revisionist camp and others belong to the traditionalist school. This survey is to demonstrate the richness of Western scholarship that needs to be academically studied and responded by Indonesian Muslim scholars so that they will not only serve as importers of knowledge but rather become the producers of knowledge and theories.
\end{abstract}

\begin{abstract}
Abstrak
Tulisan ini untuk mensurvei karya-karya sarjana al-Qur'ān dan tafsīr di Barat dalam beberapa tahun terakhir. Karya-karya ini tidak hanya ditulis oleh sarjana non Muslim, namun juga oleh sarjana Muslim. Di antara mereka ada yang termasuk kelompok revisionis radikal, namun ada pula yang bermazhab tradisionalis. Survei ini untuk menunjukkan kekayaan kesarjanaan Barat yang perlu dikaji dan direspon sarjana Muslim Indonesia secara akademik agar tidak selalu menjadi pengimpor ilmu tapi beralih menjadi produser ilmu dan teori.
\end{abstract}

Keywords: Western scholarship, Revisionis dan tradisionalis, Pendekatan kritis.

${ }^{1}$ Dosen Fakultas Ushuluddin dan Sekolah Pascasarjana UIN Syarif Hidayatullah Jakarta. E-mail: yusuf.rahman@uinjkt.ac.id. 


\section{Pendahuluan}

Kajian al-Qur'ān dan Tafsīr di Barat (Western Scholarship/EuroAmerican Scholarship) terus berkembang dan marak. Setiap tahun bahkan bulan selalu ada buku dan artikel akademik yang terbit. Mereka ditulis tidak hanya dalam bahasa Inggris, akantetapi juga bahasa Eropa (European languages), seperti Perancis, Jerman, Italia dan lain-lain. Karya-karya inipun, tidak hanya ditulis oleh sarjana non Muslim namun juga sarjana Muslim, walaupun harus diakui karya kelompok yang terakhir tidak sebanyak karya non Muslim. Gabriel Said Reynolds menggambarkan bahwa kajian al-Qur'ān dan tafsìr di Barat dalam beberapa tahun belakangan ini dengan "the Golden Age of Qur'anic Studies" (masa keemasan kajian al-Qur'ān). ${ }^{2}$

Kebanyakan dari kita, pengkaji al-Qur'ān dan tafsīr di Indonesia tidak terlalu banyak mengetahui karya-karya tersebut, apalagi membaca dan mengkritisinya. Salah satu alasannya adalah kendala bahasa. Tidak banyak di antara kita yang diberikan kemampuan untuk dapat membaca karya-karya yang ditulis langsung dari bahasa aslinya, Jerman dan Perancis, bahkan masih banyak yang kurang mampu membaca karya berbahasa Inggris. Para sarjana Barat-pun banyak yang merasa kesulitan membaca karya-karya yang berbahasa selain bahasa Inggris, sehingga karya-karya tersebut kemudian diterjemahkan ke dalam bahasa Inggris.

Oleh karena penting dan berharganya karya-karya ini untuk perkembangan kajian al-Qur'ān dan tafsīr di dunia Muslim, karya-karya kesarjanaan Barat ini sudah diterjemahkan ke dalam bahasa "Muslim", seperti ke dalam bahasa Arab, Turki, dan Persia. ${ }^{3}$ Namun penerjemahan ke dalam bahasa Indonesia masih sangat minim sekali. Tentu saja membaca karya aslinya lebih baik dari membaca karya terjemahan, karena karya terjemahan sering tidak sesuai dengan maksud karya aslinya. Belum lagi ada kemungkinan "pengkhianatan" dalam proses penerjemahan. "traduttore traditore," Penerjemah adalah pengkhianat, karena para penerjemah ada yang memanipulasi karya asli sang pengarang.

${ }^{2}$ Gabriel Said Reynolds, "Introduction: the Golden Age of Qur'ānic Studies?," dalam New Perspectives on the Qur'an: the Qur'an in Its Historical Context 2, ed. Gabriel Said Reynolds (New York: Routledge, 2011), 1-21. Tulisan tersebut sudah dijelaskan dalam Yusuf Rahman, "Tren Kajian Al-Qur'an di Dunia Barat," Jurnal Studia Insania 1, 1 (April 2013): 1-8.

${ }^{3}$ Lihat misalnya Morteza Karimi-Nia, "Contemporary Qur'ānic Studies in Iran and its Relationship with Qur'anic Studies in the West," Journal of Qur'anic Studies 14.1 (2012): 45-72, dan Mehmet Akif Koc, "The Influence of Western Qur'ānic Scholarship on Turkey," Journal of Qur'anic Studies 14.1 (2012): 9-44. 
Selain karena kendala bahasa, tidak sedikit umat Islam yang mempermasalahkan karya para sarjana non Muslim Barat dan "kafir" ini. Mereka mencurigai motif tersembunyi (hidden motive) dan ideologi dari para penulis ini, yang bagi para pengkritik bertujuan untuk menghancurkan Islam dan al-Qur'an. ${ }^{4}$ Respon tersebut sangat teologis dan polemis. Sebagai sarjana Muslim yang progresif, karya-karya tersebut perlu dibaca dan dikritisi dengan respon yang akademik pula. Yang lebih bermasalah adalah apabila belum membaca karya-karya tersebut, tapi sudah secara apriori mengeneralisir karyakarya tersebut bertujuan menghancurkan Islam.

Kendala yang ketiga yang menyebabkan kesulitan membaca dan mengkritisi hasil ijtihad sarjana Barat terhadap al-Qur'ān dan tafsìr adalah kendala akses ke karya-karya tersebut. Tidak bisa dipungkiri bahwa harga bukubuku terbitan luar negeri sangatlah mahal, dan harus dipesan ke penerbitnya di luar negeri, atau berharap jasa dari Amazon.com atau lainnya sehingga perlu biaya ongkos kirim ekstra. Begitu juga dengan harga biaya berlangganan jurnaljurnal terbaik. Padahal di jurnal-jurnal tersebutlah dapat diketahui state of the art kajian al-Qur'ān dan tafsir, dan tentu kajian-kajian akademik lainnya. Saat ini beberapa buku dan jurnal telah ditawarkan secara digital dan on line, sehingga mengurangi biaya proses pengiriman, tapi sebaliknya membutuhkan langganan internet dan kecepatan aksesnya. Yang lebih penting lagi artikelartikel up to date tentang kajian al-Qur'ān dan tafsīr yang terbit di jurnal-jurnal akademik tersebut dapat diakses dan dibaca, dan tentu saja diunduh. Memang biaya untuk dapat mengakses karya-karya ini sangatlah mahal, akan tetapi hasil yang dapat diperoleh dan diterbitkan dari membaca dan mengkritisi karya-karya ini mahal juga harganya.

Kita sangat berharap kepada institusi tempat kita mengajar, meneliti dan mengabdi, dan juga, terutama, kepada Kementerian Agama dan Kementerian Riset Teknologi dan Pendidikan Tinggi untuk dapat memfasilitasi memberikan solusi terhadap kendala-kendala tersebut, melalui program pelatihan bahasa Inggris, terutama, dan juga bahasa Eropa lainnya, ${ }^{5}$ selain bahasa Arab tentunya,

\footnotetext{
${ }^{4}$ Lihat Andrew Rippin, "The Reception of Euro-American Scholarship on the Qur'ān and Tafsīr: An Overview." Journal of Qur'anic Studies 14.1 (2012): 1-8. Seluruh artikel dalam Journal Qur'anic Studies pada nomor ini mengupas tentang respon umat Islam di Negara Arab, Iran dan Turki terhadap kajian Barat. Lihat juga makalah Yusuf Rahman, "The Indonesian Muslim Responses to the Outsiders' Studies of the Qur' an and Tafsir," yang akan dipresentasikan dalam Konferensi Internasional "Recent Trends in Qur'anic Studies" yang diselenggarakan UIN Sunan Kalijaga Yogyakarta dan International Qur'anic Studies Association (IQSA) di Yogyakarta, 4-6 Agust us 2015.

${ }^{5}$ Sebelumnya Kementerian Agama mengadakan program pelatihan bahasa Inggris bagi calon dosen selama beberapa bulan, dan banyak di antara mereka yang bisa
} 
sehingga para dosen, peneliti Indonesia mampu membaca karya-karya dunia, sehingga tidak saja nantinya mereka berperan sebagai "pengimpor" ilmu-ilmu dan teori dari Barat, ${ }^{6}$ namun menjadi "pengekspor dan produser" ilmu-ilmu dan teori.

Selain itu, untuk lebih menyemarakkan dan memperkaya sumber bacaan para mahasiswa dan dosen serta peneliti di Indonesia, Pemerintah dan juga perguruan tinggai perlu mengalokasikan banyak dana untuk membeli dan berlangganan karya-karya akademik tersebut, baik dalam bentuk cetak maupun digital on line. Hanya dengan membaca karya-karya yang bergizi dan berkualitas, karya-karya kita akan juga bergizi dan berkualitas. ${ }^{7}$

Tulisan ini akan mensurvei beberapa kajian al-Qur'ān dan tafsìr dalam bahasa Inggris yang terbit dan berkembang sejak tahun 2000an. Itu tidak berarti bahwa karya-karya sebelum tahun 2000an tidak disinggung, karena sebagaimana nanti akan dilihat banyak juga beberapa buku yang merupakan kumpulan artikel, yang sebagian artikelnya terbitan sebelum tahun 2000an. Perlu ditekankan di sini bahwa tidak ada alasan khusus kenapa dipilih karyakarya tahun 2000an selain karena pentingnya merujuk kepada karya-karya yang terbaru, bahkan seharusnya 5-10 tahun terakhir, dalam menulis karya ilmiah, untuk menunjukkan bahwa kita up to date terhadap karya yang berkembang belakangan. Tulisan ini juga dibatasi pada karya tulis yang berbentuk buku, baik dalam bentuk kumpulan tulisan ataupun utuh, bukan dalam bentuk artikelartikel di jurnal, yang tidak mungkin untuk disurvei satu persatu. Artikel-artikel yang mengkaji tentang al-Qur'ān dan tafsir kebanyakan terbit di Journal of Qur'anic Studies, ${ }^{8}$ Bulletin of the School of Oriental and African Studies ${ }^{9}$ dan

melanjutkan studi di luar negeri dengan modal bahasa yang mereka terima. Ini lebih efektif dari pada membuat dan menandatangani Memorandum of Understanding ke beberapa perguruan tinggi di luar negeri. Tanpa adanya MoU, jika para calon dosen dan peneliti tersebut sudah kualified secara bahasa dan akademik, dia akan diterima di manapun; walaupun belum memiliki MoU. Kualitas akan melahirkan dan mendatangkan banyak MoU. (Hasil diskusi dengan Prof. Dr. Jamhari Makruf)

${ }^{6}$ Johan Meuleman, misalnya, melihat bahwa banyak karya-karya Indonesia hanya menjadi pengimpor belum menjadi pengekspor ilmu. Lihat Meuleman, "South-East Asian Islam and the Globalization Process," dalam Islam in the Era of Globalization: Muslim Attitudes Towards Modernity and Identity, ed. Johan Meuleman (London: RoutledgeCurzon, 2002), 13-29, terutama 26.

${ }^{7}$ Istilah Fuad Jabali, dosen UIN Jakarta, "jika kita memakan makanan yang sudah basi, bekas dan tidak bergizi, maka kita akan sakit perut dan mencret.” Begitu pula halnya jika kita membaca bacaan yang sudah usang dan second hand (bukan dari karya aslinya) dan tidak bergizi atau berkualitas.

${ }^{8}$ Diterbitkan sejak tahun 1999, dua kali terbit dalam setahun, oleh Edinburgh University Press untuk Center for Islamic Studies SOAS.

${ }^{9}$ Diterbitkan sejak tahun 1920 oleh Cambridge University Press. 
di beberapa jurnal yang lain, seperti Islam and Muslim Christian Relations, ${ }^{10}$ Muslim World, ${ }^{11}$ dan lain-lain.

\section{Perkembangan Publikasi Kajian al-Qur'an di Barat Buku Referensi}

Sebagaimana pendapat Reynolds, "the most significant new publication" pada tahun 2000an adalah Encyclopaedia of the Qur'an $(E Q)^{12}$ yang disunting Jane Dammen McAuliffe, sebanyak 5 volume plus Index, yang terbit sejak tahun 2001-2006. McAuliffe adalah salah satu dari sedikit sarjana Barat berjenis kelamin perempuan yang menekuni dan mengkaji al-Qur'an. Disertasinya di Universitas Toronto Kanada telah diterbitkan dengan judul Qur'anic Christians: an Analysis of Classical and Modern Exegesis. ${ }^{13}$

Berbeda dengan Encyclopaedia of Islam, yang juga diterbitkan Brill, susunan artikel di $E Q$ mengikuti judul-judul entri berbahasa Inggris, bukan berbahasa Arab. Misalnya judul entri "Exegesis of the Qur'an" lebih digunakan dari pada "al-Tafsìi," "Marriage and Divorce" dari pada "al-Nikāh" atau "alTalāq," dan seterusnya. Tentu ada kelebihan dan kekurangan dengan penyusunan seperti ini. Stefan Wild, misalnya, mengkritisi bahwa selain ada manfaat yang didapat dari penulisan judul entri dengan bahasa Inggris, namun ada juga masalah, misalnya untuk menemukan nama-nama Nabi dalam alQur'an Nama Ibrāhīm didapatnya di entri "Abraham," ${ }^{14}$ nama Yūsuf di entri "Joseph" dan juga untuk beberapa nama tempat.

$E Q$ memuat sekitar 150 entri di setiap jilidnya, dan ditulis oleh sarjana yang ahli di bidangnya. Para peresensi $E Q$ umumnya sepakat bahwa $E Q$ sangat penting untuk dijadikan referensi utama kajian al-Qur'ān dan tafsìr. ${ }^{15}$ Para pengkaji al-Qur'ān dan tafsīr yang ingin meneliti dan menulis tentang temateman al-Qur'ān akan lebih baik jika merujuk dahulu ke EQ terutama karena di setiap entrinya terdapat bibliografi yang memuat sumber-sumber primer dan

${ }^{10}$ Diedit oleh University of Birmingham, Inggris dan Monash University Australia.

${ }^{11}$ Jurnal ini didirikan sejak tahun 1911 dan disponsori oleh Hartford Seminary, Hartford, CT Amerika Serikat dan diterbitkan oleh MacDonald Center dan WileyBlackwell.

${ }^{12}$ Jane D. McAuliffe, Encyclopaedia of the Qur'ān (Leiden: Brill, 2001-2006), 5 jilid + indeks.

${ }^{13}$ McAuliffe, Qur'anic Christians: an Analysis of Classical and Modern Exegesis (Cambridge; New York: Cambridge University Press, 1991).

${ }^{14}$ Stefan Wild, "Review of EQ," Die Welt des Islams 43, 2 (2003): 294-297.

${ }^{15}$ Lihat Wild, "Review of $E Q$," dan Mustafa Shah, "Review $E Q$ volume 4, 5, Indices," Bulletin of the School of Oriental and African Studies 71, 2 (2008): 365-366. 
sekunder. Para penulis entri tidak hanya dari sarjana non Muslim namun juga ada beberapa sarjana Muslim. Prof. Azyumardi Azra termasuk salah satu editor $E Q$ ini. $E Q$ merupakan ensiklopedi referensi yang pertama tentang al-Qur'ān yang terbit dalam bahasa Inggris.

Saat ini $E Q$ sudah didigital/on line-kan sehingga bisa lebih accessible, dan sudah dalam rencana penambahan beberapa tema dan pembahasan yang mungkin terlewatkan dan kurang terwadahi dalam edisi yang terbit sebelumnya dalam bentuk Supplement. ${ }^{16}$

Akan tetapi, Muzaffar Iqbal, pendiri dan presiden Center for Islam and Science di Kanada, kurang bisa menerima karya $E Q$ ini karena baginya karya ini didasarkan pada pendekatan yang relativistik terhadap al-Qur'an, yang baginya tidak sesuai dengan dasar keilahian al-Qur'an. ${ }^{17}$ Ia menulis:

"A quick examination of the list of contributors, however, reveals that an overwhelming majority of contributors holds only one foundational perspective on the Qur'an - a modernist, relativistic, evolutionary perspective that takes the text of the Qur'an as a human construction and that calls for a historicist-hermeneutic approach to it."

Untuk merespon ini, sebagai tandingannya, Iqbal sedang mempersiapkan bersama dengan beberapa sarjana Muslim untuk menerbitkan The Integrated Encyclopedia of the Qur'ān. ${ }^{18}$ Hingga saat ini sudah terbit vol. 1 (A-Bea), namun penulis belum bisa mengakses buku ini.

Sebagai catatan, huruf I dalam IEQ tampaknya punya arti tersendiri karena bisa juga diartikan dengan Islamic, selain Integrated. Kemunculan IEQ ini tampaknya sudah diprediksikan M. Arkoun di dalam entrinya di volume pertama $E Q$. Ia menulis:

“The project of publishing an Encyclopaedia of the Qur'an that is conceived and realized with respect for the critical order of rational processes is long overdue. This delay confirms this article's position on the historical and epistemological discrepancy between philosophic and scientific reasons, as

${ }^{16}$ Lihat Journal of Qur'anic Studies, "Planning Begins for Encyclopaedia of the Qur'ān: Supplement," Journal of Qur'anic Studies 15, 2 (2013): 140-141.

${ }_{17}$ Muzaffar Iqbal, 'The Qur'ān, Orientalism, and The Encyclopaedia of the Qur'an', Journal of Qur'anic Research and Studies 3:5 (2008), 11. The article is available at http://www.cis-ca.org/muzaffar/EQ-Rev.pdf

${ }^{18}$ Lihat Muzaffar Iqbal, "Integrated Encyclopedia of the Qur'ān: Raison d'etre \& Project Summary," Islam \& Science 8, 1 (Summer 2010): 33-47. 
practiced today in the West and elsewhere, and Islamic reason as it asserts itself in its positions on Islam as well as in political action, legal codes, educational systems and behaviors which encourage the traditional. As long as the Islamic logical universe continues to function within the dogmatic enclosure of its historical form as received since the thirteenth and fourteenth centuries, there will be a place for a parallel Islamic encyclopedia of Islam and, all the more, an Islamic encyclopedia of the Qur'ān." $" 19$

Selain penerbitan $E Q$, Oliver Leaman juga menerbitkan ensiklopedia alQur'ān dengan judul The Qur'an: An Encyclopedia (QE) dalam 1 jilid. $^{20}$ Ensiklopedia ini berisi 350 entri yang ditulis oleh sekitar 43 sarjana, dengan berbagai latar belakang. Dalam hal ini Leaman menulis:

"[C]ontributors to this volume come from a wide variety of backgrounds. Some are Muslims, some are not, and some have no religious beliefs whatsoever. They are united in being interested in the Qur'an. The authors come from all doctrinal backgrounds and readers should expect to find a wide variety of views in this book. We do not in any way, attempt to present the last word on any of the topics raised, quite the reverse. The editor has included accounts that often go against each other in order to illustrate to readers the contested nature of interpretation that exists in the subject area. What this volume represents is very much interpretation and commentary, tafsir in Arabic, an attempt at understanding the text of the Qur'an." ${ }^{1}$

Menarik untuk membandingkan antara entri di $E Q$ dan $Q E$, walaupun beberapa penulis entrinya juga sama, namun isinya dalam beberapa hal banyak berbeda.

Selain menyunting $E Q$, McAuliffe juga menyunting buku dengan judul Cambridge Companion to the Qur'an. ${ }^{22}$ Buku ini terdiri dari 5 bagian, bagian pertama berisi kajian sarjana tentang sejarah pembentukan al-Qur'ān, yang dibahas F. Donner, C. Gilliot, dan M. Motzki; bagian kedua tentang

${ }^{19}$ Arkoun, “Contemporary Critical Practices and the Qur'ān,” EQ 1: 412-430. Kutipan ada di 428. Penulisan miring ditekankan.

${ }^{20}$ Oliver Leaman, The Qur'an: An Encyclopedia (London: Routledge, 2006).

${ }^{21}$ Leaman, The Qur'an, ix.

${ }^{22}$ McAuliffe, Cambridge Companion to the Qur'ann (Cambridge, 2006). Edisi online dipublikasikan bulan Maret 2007 dengan alamat http://dx.doi.org/10.1017/CCOL0521831601. 
"Description and Analysis" yang berturut-turut dibahas D. Madigan A. Neuwirth, dan W. Graham dan N. Kermani tentang tema, struktur al-Qur'ān, serta pembacaannya; bagian ketiga "Transmission and Dissemination" membahas transmisi al-Qur'an dalam bentuk manuskrip (F. Leemhuis) dan kaligrafi (S. Blair dan J. Bloom); bagian keempat "Interpretations and Intellectual Traditions" mendiskusikan penafsiran al-Qur'ān oleh umat Islam (McAuliffe) dan kesarjanaan Barat tentang al-Qur'ān (A. Rippin); dan diakhiri dengan bagian kelima "Contemporary Readings" tentang penafsiran perempuan (A. Barlas), penafsiran politis (S. Wild), dan penafsiran intra agama (A. Sachedina).

Jika McAuliffe menyunting buku atas nama Penerbit Cambridge, Andrew Rippin menyunting buku atas nama Penerbit Blackwell dengan judul Blackwell Companion to the Qur'an. ${ }^{23}$ Tujuan Rippin dalam menyunting buku ini adalah untuk menjadi pengantar tentang al-Qur'an bagi mereka yang kurang memiliki pengetahuan tentang teks dan juga untuk memberi kesempatan bagi para sarjana untuk memperluas wawasan mereka untuk tidak hanya mengetahui pendekatan yang mu'tabar ("accepted" approaches) dalam kajian al-Qur'an. ${ }^{24}$ Pembahasan buku ini dibagi ke dalam 5 bagian, didukung dengan bibliografi, Indeks Tokoh, Tempat, dan Topik, serta Indeks Ayat al-Qur'ān. Bagian pertama tentang "Orientation"; bagian kedua tentang "Text", yang membahas tentang teks dan konteks al-Qur'ān; ketiga "Content” (Isi), seperti tentang Tuhan, Nabi, hingga Seks dan Keluarga; bagian keempat "Interpretation" seperti penafsiran sufistik, penafsiran Isma'ili dan Syi'i Imami; dan bagian kelima tentang “Application" yang berisi ulum al-Qur'an, teologi, hukum Islam, dll.

Kedua buku suntingan di atas, terbit pada tahun yang sama (2006), dan beberapa penulisnya, seperti Rippin, McAuliffe, Neuwirth, Kermani menulis artikel yang berbeda. Buku suntingan Rippin lebih memuat banyak artikel dan penulis. Beberapa tema hampir sama, seperti sejarah al-Qur'ān, dan penafsiran al-Qur'ān, akan tetapi masing-masing mengambil beberapa sudut kajian yang berbeda.

Rippin sendiri telah menyunting dan mengumpulkan karya-karyanya yang tersebar di beberapa artikel dan bagian buku ke dalam satu buku berjudul The Qur'an and Its Interpretative Tradition. ${ }^{25}$ Buku ini diterbitkan dalam edisi

${ }^{23}$ Andrew Rippin (ed.), The Blackwell Companion to the Qur'an (Oxford: Blackwell Publishing, 2006). Judul-judul untuk masing-masing artikel bisa dilihat di http://au.wiley.com-/WileyCDA/WileyTitle/productCd-1405117524.html.

${ }^{24}$ Rippin, Blackwell Companion, x.

${ }^{25}$ Rippin, The Qur'an and Its Interpretative Tradition (Burlington, Vermont: Ashgate Publishing Company, 2001). 
Variorum Collected Studies Series. Berbeda dengan edisi Variorum lainnya yang mengumpulkan artikel-artikel dari beberapa sarjana dalam suatu bidang ilmu, ${ }^{26}$ maka buku ini secara khusus mengumpulkan karya-karya Rippin. Model kumpulan tulisan ini menarik karena bisa menunjukkan perkembangan pemikiran seseorang dan juga metode yang digunakan selama ini, serta - yang lebih penting -- bisa membaca secara utuh dan komprehensif pemikiran seorang tokoh.

Sebagaimana diketahui, Rippin termasuk bermazhab revisionis dan sangat dipengaruhi John Wansbrough. Revisionis adalah suatu pendekatan yang secara radikal meragukan sumber-sumber yang ditulis Muslim terkait dengan perkembangan Islam pada masa awal, karena bagi kelompok ini sumber-sumber tersebut, seperti sirrah Nabi dan al-Qur'an, ditulis dan dibukukan beberapa dekade setelah peristiwa itu terjadi. Disertasi Rippin berjudul “The Qur'ānic Asbāb al-Nuzūl Material: an Analysis of Its Use and Development in Exegesis," di McGill University Kanada tahun 1981 di bawah bimbingan Charles J. Adams. Namun ia lebih banyak melakukan penelitiannya di Inggris dan mendapat bimbingan dari Wansbrough. Beberapa bagian dari disertasinya telah diterbitkan di beberapa jurnal, dan kini dikumpulkan dalam buku kumpulan artikel ini.

Di antara artikelnya yang mendukung dan memperjelas pemikiran dan metode Wansbrough, terutama di artikelnya yang berjudul "Literary Analysis of Qur'ān, Tafsìir and Sirra: the Methodologies of John Wansbrough," yang sebelumnya diterbitkan di buku Approaches to Islam in Religious Studies, ${ }^{27}$ dan "Quranic Studies, part IV: Some Methodological Notes. ${ }^{28}$ Yang pertama menjelaskan tentang pendekatan literer karena Wansbrough berkeyakinan bahwa sumber-sumber Islam awal bukan merupakan dokumen historis, akan tetapi dokumen sejarah keselamatan "salvation history," sehingga tidak bisa dikaji dengan pendekatan historis. Artikel yang kedua tentang perkembangan tafsir, mulai dari haggadik, halakik, masoretik, retorik dan alegorik. Semakin awal suatu penafsiran maka semakin sederhana penafsiran tersebut. Jika

${ }^{26}$ Lihat misalnya, dalam kajian al-Qur'an, Rippin (ed.), The Qur'an: Formative Interpretation (Burlington, Vermont: Ashgate Publishing Company, 1999), dan A. Rippin (ed.), The Qur'ān: Style and Contents (Brookfield, Vermont: Ashgate Publishing Company, 2001).

${ }^{27}$ Rippin, "Literary Analysis of Qur'ān, Tafsir and Sira: the Methodologies of John Wansbrough," di Approaches to Islam in Religious Studies, ed. R. C. Martin (Tucson: University of Arizona Press, 1985), 151-163, 227-232.

${ }^{28}$ Rippin, "Quranic Studies, part IV: Some Methodological Notes," Method and Theory in the Study of Religion IX (1997): 39-46. 
ditemukan penafsiran yang berisi retorika atau puisi-puisi di dalam tafsir awal, maka ia patut dicurigai. ${ }^{29}$

Jika Rippin merupakan representasi dari kelompok revisionis, Angelika Neuwirth adalah salah satu penentang utama kelompok revisionis. Kumpulan tulisannya, yang sebelumnya ditulis dalam bahasa Jerman di antara tahun 19902012, telah diterjemahkan ke dalam bahasa Inggris dalam karyanya Scripture, Poetry and the Making of a Community: Reading the Qur'an as a Literary Text ${ }^{30}$ yang tesis utamanya adalah untuk menekankan bahwa al-Qur'ān adalah "a late antique text." Ia ingin membantah pandangan para sarjana yang selama ini selalu memfokuskan kajian mereka pada sumber eksternal al-Qur'ān, dibandingkan untuk mengkaji artefak sastra yang ada dalam teks al-Qur'ān itu sendiri. Perkembangan kajian al-Qur'ān yang seperti ini, bagi Neuwirth, menimbulkan “epistemic pessimism.” Pesimisme epistemik ini muncul karena:

"Not only are there vast corpora of Islamic learning that are rashly dismissed by a majority of scholars as useless for Qur'anic studies, such as the sira (the biography of the Prophet) and often Islamic tradition as a whole, but equally there seems to be little interest in the pagan Arab background of the Qur'anic event. Thus, a number of texts and traditions are excluded from the scope of Qur'anic scholarship for the sake of a principal decision: to relocate the Qur'an out of Arabia into an indeterminate Christian space and to reinterpret it not as the transcript of a prophetical communication, but as an anonymous compilation more or less completely dissociated from the historical event of the ministry of Muhammad." 31

Pernyataan ini sangat kentara sekali membantah pandangan Wansbrough dan kelompok revisionis lainnya yang tidak mempercayai sumber-sumber Muslim. Berbeda dengan kajian kelompok revisionis, Neuwirth, di dalam bukunya ini, bukan dalam rangka mengkaji al-Qur'ān sebagai dokumen historis, akantetapi sebagai artifak sastra. Oleh karena itu ia ingin mengkaji karakter

${ }^{29}$ Pendekatan Wansbrough banyak dikritik sarjana Barat dan Muslim. Lihat misalnya, Herbert Berg, "The Implications of, and Opposition to, the Methods and Theories of John Wansbrough," Method \& Theory in the Study of Religion 9, 1 (1997): $3-22$.

${ }^{30}$ Angelika Neuwirth, Scripture, Poetry and the Making of a Community: Reading the Qur'an as a Literary Text (London: Oxford University Press in association with the Institute of Ismaili Studies, 2014).

${ }^{31}$ Neuwirth, "Introduction: Epistemic Pessimism in Qur'anic Studies," Scripture, Poetry and the Making of a Community, xix. 
sastra dari al-Qur'ān, dengan mengkaji intertekstualitas di antara surat-surat awal al-Qur'ān dengan surat-surat yang belakangan, dan juga antara al-Qur'ān dengan tradisi Bibel. Itulah yang dilakukan terutama di Bagian Kedua "The Liturgical Qur'an and the Emergence of the Community" dan Bagian Ketiga "Narrative Figures between the Bible and the Qur'an" dari bukunya. Walaupun kajiannya adalah kajian intertekstualitas dan intratekstualitas terhadap karakter sastra al-Qur'ān, namun tujuan akhirnya adalah untuk membantah tesis kelompok revisionis, yang menyatakan bahwa al-Qur'ān lahir bukan di Arabia. “The Qur'an," Neuwirth berkesimpulan, “judged upon its literary appearance, presents itself (in addition to its character as a mantic manifestation) as the transcript of an ongoing debate of the theological problems that were present in Late Antiquity." ${ }^{2}$

Perdebatan akademik antara Rippin dan Neuwirth tidak hanya terbaca dalam publikasi kedua buku di atas, dan juga artikel-artikel akademik lainnya. Dalam Konferensi Tahunan International Qur'anic Studies Association (IQSA) pada 21-24 November 2014 di San Diego California, Amerika Serikat, Rippin, sebagai Presiden IQSA pada tahun itu, mengundang Neuwirth untuk menjadi Pembicara Inti dalam Konferensi dengan mempresentasikan makalah berjudul “Qur'anic Studies and Historical-Critical Philology: The Qur'an's Staging, Penetrating, and Eclipsing of Biblical Tradition" dan Rippin menjadi Responden terhadap pemaparan makalah Neuwirth dengan judul "Angelika Neuwirth and Philology: A Response to the Keynote Lecture." ${ }^{33}$ Forum ini menunjukkan bahwa walaupun mereka memiliki pandangan yang sangat kontradiktif, namun mereka memperdebatkannya secara akademik baik secara langsung face to face, maupun dengan tulisan akademik.

\section{Kumpulan Makalah Hasil Seminar}

Sarjana-sarjana pengkaji al-Qur'ān dan tafsīr di Barat sering mengadakan seminar untuk mempresentasikan hasil penelitian, menjalin interaksi akademik dengan sarjana sebidang, atau merespon terhadap perkembangan teori tertentu, yang kemudian makalahnya diterbitkan dalam satu buku. Salah satunya adalah kumpulan artikel hasil dari konferensi di University of Toronto pada tahun 1997, namun baru diterbitkan tahun 2003. McAuliffe bersama Barry D. Walfish

32 Neuwirth, "Introduction: Epistemic Pessimism in Qur'anic Studies," Scripture, Poetry and the Making of a Community, xxiii.

33 Lihat agenda Konferensi secara keseluruhan di https://iqsaweb.wordpress.com/meetings-/am2014/. Makalah keduanya dapat diakses di https://iqsaweb.wordpress.com/publications/papers/. 
dan Joseph W. Goering menyunting buku With Reference for the Word: Medieval Scriptural Exegesis in Judaism, Christianity, and Islam. ${ }^{34}$ Konferensi ini mempertemukan sarjana kajian Bibel dalam agama Yahudi dan Kristen, dan sarjana kajian tafsir, yang bertujuan untuk menemukan berbagai "opportunities for academic interaction with college in cognate fields of medieval biblical exegesis." Oleh karena itu, para penulis dalam buku ini terdiri dari sarjana kajian Bible dalam agama Yahudi dan Kristen serta sarjana kajian al-Qur'an. Buku ini dibagi tiga bagian, bagian pertama dan kedua tentang penafsiran Bible dalam tradisi Yahudi dan Kristen secara berurutan, dan bagian ketiga penafsiran al-Qur'an. McAuliffe mendiskusikan kronologi dan klasifikasi tafsir al-Qur'an pada Abad Pertengahan, dan juga hubungannya dengan tafsir modern; Hava Lazarus Yafeh dan G. Bowering membahas penafsiran Shi'i dan sufi, A. Neuwirth mendiskusikan posisi Yerusalem dalam tafsir, Rippin tentang kata asing dalam al-Qur'ān, sementara S. Wild mendiskusikan penafsiran Q. 3:7.

Konferensi yang diadakan untuk merespon teori tertentu dalam kajian alQur'ān dapat dilihat dalam buku suntingan Gabriel Said Reynolds berjudul The Qur'an in Its Historical Context, ${ }^{35}$ yang merupakan kumpulan makalah yang diseminarkan bulan April 2005 di University of Notre Dame, untuk merespon tesis para Revisionis, terutama Gunter Luling dan Christoph Luxenberg. Yang pertama menekankan bahwa Ur-Qur'an (Qur'an yang orisinal/kuno) banyak mengambil dari bait-bait pujian komunitas Kristiani di Mekah, sementara yang kedua menekankan bahwa Kristen Syiria (Syriac Christianity) sangat penting dalam perkembangan al-Qur'an. ${ }^{36}$

Bagian pertama buku ini berjudul "Linguistic and Historical Evidence" berisi lima artikel yang menekankan penggunaan filologi dan sejarah dalam kajian al-Qur'an, sebagai kritik terhadap Luling dan Luxenbergh yang menghindari kajian historis dalam teori filologinya; Bagian kedua "The Religious Context of the Late Antique Near East" memiliki 5 artikel yang menekankan hubungan antara al-Qur'an dengan agama Kristen. Di sini para peneliti menunjukkan bagaimana penguasaan terhadap bahasa, agama dan sejarah di daerah berkembangnya Islam pada saat itu, dapat membantu menjelaskan tentang perkembangan Islam pada masa awal. Bagi Reynolds, ini

${ }^{34}$ McAuliffe, Barry D. Walfish dan Joseph W. Goering (eds.), With Reference for the Word: Medieval Scriptural Exegesis in Judaism, Christianity, and Islam (Oxford: Oxford University Press, 2003).

${ }^{35}$ Reynolds (ed.), The Qur'ān in Its Historical Context (New York: Routledge, 2008).

${ }^{36}$ Penjelasan tentang tesis Luling dan Luxenberg bisa dilihat di Reynolds, "Introduction," The Qur'ān in Its Historical Context, 10-17. 
menunjukkan bahwa para pengkaji al-Qur'ān tidak hanya cukup menguasai bahasa Arab, akan tetapi juga bahasa klasik dan Semitik. ${ }^{37}$ Bagian Ketiga "Critical Study of the Qur'an and the Muslim Exegetical Tradition" mengajak untuk melakukan studi kritis terhadap al-Qur'ān. Bagian ini memuat dua artikel, yang pertama menunjukkan bahwa praktek perubahan (emendation) terhadap teks al-Qur'an sudah pernah didiskusikan oleh sarjana Muslim Abad Pertengahan karena alasan kesulitan membaca rasm teks dan juga alasan teologis, sementara Rippin menunjukkan bahwa diskusi tentang adanya kata asing dalam al-Qur'an tidak hanya muncul pada masa modern, akan tetapi juga sudah didiskusikan sarjana Muslim sebelumnya.

Yang juga menarik dari buku suntingan ini adalah "Foreword" dari Daniel A. Madigan yang juga mengkritik Luling dan Luxenberg. Ia menulis:

"The claim that the underlying structure and numerous element of the [Qur'anic] text are originally Christian seems to reveal a desire to dispossess the Muslim community of its foundation and greatest treasure.... New and fruitful readings of the Qur'ān will not result from competitive and conflictual analysis. They will be catalyzed by a collaboration among all those who, whether believers or not, take the text seriously not simply as an historical artefact but as a canon of scripture for a contemporary community." 38

Respon terhadap teori Luling dan Luxenbergh juga dapat dilihat dari buku The Qur'ān in Context: Historical and Literary Investigations into the Qur'ānic Milieu, yang disunting Neuwirth, Nicolai Sinai, dan Michael Marx. ${ }^{39}$ Buku ini merupakan kumpulan makalah seminar yang diselenggarakan dalam bahasa Jerman pada tanggal 21-25 Januari 2004 dengan judul "Historische Sondierung und methodische Reflexionen zur Koranexegese - Wege zur Rekonstruktion des vorkanonischen Koran," 40 namun baru terbit dalam bahasa Inggris tahun 2010. Buku ini memuat 27 artikel, yang terdiri dari dua bagian. Pertama "The Qur'ān Historical Context," dan kedua "Contextualizing the Qur'ān.” Dalam "Introduction”nya, Sinai dan Neuwirth mempromosikan teori intepretasinya, yaitu "contextual reading":

${ }^{37}$ Reynolds, "Introduction," The Qur'ān in Its Historical Context, 17.

${ }^{38}$ Madigan, "Foreword," The Qur'ān in Its Historical Context, xiii.

${ }^{39}$ Neuwirth, Nicolai Sinai, dan Michael Marx (eds.), The Qur'an in Context: Historical and Literary Investigations into the Qur'anic Milieu (Leiden: Brill, 2010).

${ }^{40}$ Reynolds, "Introduction: the Golden Age of Qur'ānic Studies," 8, n. 43. 
"A truly contextual reading of the Qur'an (as opposed to a mere reading of the Qur'an's context) must not content itself with dissolving the Qur'an into its Christian, Jewish, and other "sources," but at least allow for the possibility that the Qur'an may turn out to be a text of its own, i.e., a discourse - or, rather, a series of diachronically contiguous discourse-possessed of its own peculiar theological agenda and literary logic." ${ }^{\prime 1}$

Neuwirth dan Sinai berpendapat bahwa pembacaan kontekstual seperti ini bisa diterima oleh kebanyakan umat Islam, karena beberapa sarjana Muslim, seperti Amin al-Khuli, Fazlur Rahman, Nasr Abu Zayd telah menggunakan pendekatan kontekstual ini terhadap al-Qur'ān. Sebelum melakukan pendekatan kontekstual ini, Neuwirth dan Sinai mengajukan analisis historis, tapi bukan dalam arti merekonstruksi sistem yang sudah ada, melainkan untuk "delineates the ground upon which any attempt to derive contemporary guidance from the canon must operate (rather than eroding this very ground, as some would object). ${ }^{42}$

Bagi Rippin, buku ini, yang di bagian pertama mendiskusikan beberapa aspek dari konteks politik, ekonomi, linguistik dan budaya al-Qur'ān, yang sering disebut dengan konteks "late antique," ingin mengkounter tesisnya John Wansbrough yang berkesimpulan bahwa Islam bermula bukan dari Hijaz, atau juga membantah konsep wilayah Arabia yang jăhiliyya. Lebih dari itu, Rippin melihat artikel-artikel di bagian ini untuk merespon dan membantah teori Karl Heinz Ohlig dan Gerd R. Puin dari kelompok Inārah: Institut zur Erforschung der fruehen Islamgeschichte und des Koran. ${ }^{43}$ Begitu juga di bagian kedua yang membahas tentang aspek literer dari al-Qur'ān, yang mempromosikan untuk membaca al-Qur'an sebagai proses dan sebagai diskursus, juga untuk membantah pandangan Wansbrough tentang kanonisasi al-Qur'an pada masa belakangan.

Sebagaimana bisa dilihat, bahwa kedua buku suntingan hasil seminar sama-sama ingin merespon teori revisionis Wansbrough, dan juga teori revisionis yang dikembangakan kelompok Inarah di Jerman.

Buku suntingan hasil seminar yang ketiga adalah New Perspectives on the Qur'ān: The Qur'ān in Its Historical Context 2, yang disunting Reynolds. ${ }^{44}$

${ }^{41}$ Sinai dan Neuwirth, "Introduction," dalam The Qur'an in Context, 12-13.

${ }^{42}$ Sinai dan Neuwirth, "Introduction," The Qur'an in Context, 14.

${ }^{43}$ Rippin, "Review of The Qur'an in Context,"Journal of the American Oriental Society 131, 3 (2011): 470-473.

${ }^{44}$ Reynolds (ed.), New Perspectives on the Qur'ān: The Qur'ān in Its Historical Context 2 (New York: Routledge, 2011). 
Buku ini merupakan kompilasi makalah yang dipresentasikan pada konferensi yang diadakan di University of Notre Dame 19 - 21 April 2009. Konteks historis dalam judul tersebut merujuk kepada pertanyaan hubungan antara alQur'an dengan Late Antiquity. Apakah al-Qur'an muncul dari tradisi JudeoKristen atau dari konteks Late Antiquity.

Yang menarik dalam edisi ini adalah sarjana-sarjana dari kelompok Revisionis bertemu dan berdebat dengan para pengkritiknya, dan sama-sama berkontribusi dalam seminar ini. Dari kelompok Revisionis terdapat Rippin, Puin, Luxenberg, Hawting, dan para penentangnya terdapat Donner, Sidney Griffith, Devin Stewart dll. Memang tidak nampak dalam jajaran penulis dari kelompok Neuwirth dan Sinai.

Di bagian akhir Introduction-nya, Reynolds menggambarkan bahwa walaupun terdapat perbedaan antara kelompok revisionis dan traditionalis tapi secara umum "recent critical scholarship on the Qur'ān has been largely shaped by a sympathetic response to the text of the Qur'an̄n itself. Instead of polemic, scholars involved in this movement are generally motivated by intellectual appreciation, even fascination to the text of the Qur'ān itself." ${ }^{45}$ Suatu pernyataan yang perlu dibuktikan lebih lanjut dengan kajian terhadap karyakarya tersebut.

\section{Kumpulan Artikel dalam Bentuk Reprint}

Selain mempublikasikan makalah-makalah yang dipresentasikan dalam Seminar, mencetak kembali dan menyunting tulisan-tulisan tentang al-Qur'ān dan tafsīi dan disatukan dalam satu buku tampaknya sedang menjadi tren publikasi di Barat. Paling tidak ada dua suntingan buku model seperti ini. Yang pertama yang disunting oleh Colin Turner dengan judul The Koran: Critical Concepts in Islamic Studies. ${ }^{46}$ Buku ini memiliki 4 volume, dengan volume I tentang "Provenance and Transmission"; volume II, "Themes and Doctrines," volume III, "Style and Structure"; volume IV, "Translation and Exegesis." Keseluruhannya berisi 75 reprint (pencetakan ulang) dari 75 artikel jurnal dan bagian buku, yang kesemuanya berbahasa Inggris, yang terbit mulai tahun 1891 sampai 2002. Paling tidak ini bisa dijadikan sebagai survei terhadap kajian alQur'an yang berkembang saat ini di Barat. Menarik untuk membaca pengantar yang ditulis Turner sehingga dia memberi judul buku ini Critical Concepts. Ia menulis:

${ }^{45}$ Reynolds, “Introduction,” New Perspectives on the QUr'ān, 21.

${ }^{46}$ Colin Turner, The Koran: Critical Concepts in Islamic Studies (London: RoutledgeCurzon, 2004). Untuk melihat judul-judul artikel secara lengkap di setiap volume, lihat http://www.mehdi-azaiez.org/The-Koran-critical-concepts-in?lang=fr. 
"We must remind ourselves that these volumes form part of a series whose rubric - Critical Concepts - must, by its very definition, exclude the vast majority of works written about the Koran by Muslim scholars who happen to believe in its veracity and authenticity. For it remains a sad fact that critical approaches to the Koran by committed Muslim scholars are astonishingly thin on the ground" 47

Tidak banyak memang karya sarjana Muslim yang dimasukkan dalam kumpulan tulisan ini, walaupun ada karya Fazlur Rahman dan lainnya. Yang menjadi masalah utama dalam pencetakan ulang artikel-artikel dalam buku ini bagi Rippin adalah masalah "Copyright." 48 Rippin mempermasalahkan beberapa artikel yang diterbitkan ulang di sini belum mendapatkan izin dari penerbit awal.

Selain Turner, yang mengumpulkan artikel terkait dengan al-Qur'ān, maka Mustafa Shah menyunting artikel-artikel terkait dengan Tafsir, dengan judul Tafsir: Interpreting the Qur'ān. ${ }^{49}$ Buku ini juga terdiri dari 4 volume, dan memuat 81 artikel sejak tahun 1967. Buku ini menggambarkan perkembangan kajian tafsir oleh para sarjana selama ini. Volume I "Tafsir: Gestation and Synthesis" yang terdiri dari Bagian 1: "History and Development" Bagian 2 "Dating Early Exegetical Texts"; Volume II, "Tafsir: Theory and Constructs" terdiri dari "Procedural and Conceptual Devices"; volume III "The Scholarship of Tafsir"; volume IV "Tafsir: Topics, Themes and Approaches, yang terdiri dari "Topics and Themes of Exegesis," dan "Modern Development in Exegesis: Interpretation and Hermeneutics."

Dua suntingan buku di atas, yang mengumpulkan dan mencetak ulang artikel-artikel yang ada selama ini, paling tidak menggambarkan sejauh mana kajian al-Qur'ān dan tafsīr sudah berkembang dalam kesarjanaan Barat dalam berbagai aspeknya.

\section{Buku Berasal dari Disertasi}

Selain publikasi buku-buku yang merupakan reprint (pencetakan ulang) dan suntingan terhadap beberapa artikel dan juga kumpulan makalah konferensi,

${ }^{47}$ Lihat Turner, The Koran, 1.

${ }^{48}$ Lihat Rippin, "Review of The Koran," Bulletin of the School of Oriental and African Studies 69, 1 (February 2006): 141-142.

${ }^{49}$ Mustafa Shah (ed.), Tafsir: Interpreting the Qur'an (London: Routledge, 2013). Judul-judul secara lengkap seluruh artikel bisa dilihat di https://www.routledge.com/products-/9780415580748 
beberapa buku diterbitkan oleh sarjana al-Qur'ān dan tafsīr di Barat secara utuh yang meliputi beberapa tema. Mayoritas buku-buku ini merupakan format ulang terhadap disertasi mereka.

Karya pertama dari kategori ini membahas tema yang masih belum selesai dikaji sarjana Barat yaitu tentang sejarah teks al-Qur'ān, yaitu karya Keith E. Small yang berjudul Textual Criticism and Qur'ān Manuscripts. ${ }^{50}$ Menurut Fred Donner kajian kritis terhadap al-Qur'ān dipengaruhi oleh tiga perkembangan kajian al-Qur'ān. ${ }^{51}$ Pertama adalah terbitnya karya G. Luling tentang Uber den Ur-Qur'ān tahun 1974 yang berkesimpulan bahwa teks alQur'ān banyak mengambil bait-bait pujian komunitas Kristiani di Mekah, dan karya J. Wansborugh Qur'ānic Studies tahun 1977. Penerbitan karya-karya ini mempengaruhi munculnya ketertarikan terhadap kajian "al-Qur'ān edisi kritis," namun sayangnya tidak banyak bukti-bukti untuk mendukung hipotesis mereka.

Perkembangan kedua adalah penemuan manuskrip al-Qur'ān di tahun 1970an, yang diperlihatkan oleh tim sarjana dari Jerman dan Yaman, dari usaha restorasi Masjid Jami’ Șan‘à' Yaman. Penemuan fragmen-fragmen al-Qur’ān ini sangat penting bagi sejarah awal teks al-Qur'ān dan juga transmisinya pada masa awal, akan tetapi kajian terhadap fragmen-fragmen ini tidak banyak terpublikasikan, sehingga tidak banyak yang bisa mengaksesnya. Foto-foto dari fragmen-fragmen ini disimpan dan hanya bisa diakses oleh sarjana-sarjana yang berada di Saarbrucken Jerman. ${ }^{52}$

Perkembangan ketiga adalah berita yang diumumkan di tahun 1990 bahwa arsip foto-foto manuskrip yang dilakukan G. Bergstraesser setelah Perang Dunia Pertama yang dijadikan sebagai dasar untuk membuat edisi kritis al-Qur'ān, yang sebelumnya diberitakan sudah hancur dan hilang pada Perang Dunia Kedua, ternyata masih ada dan saat ini berada di tangan Angelika Neuwirth dan proyeknya yang berjudul Corpus Coranicum. ${ }^{53}$ Proyek inilah yang

${ }^{50}$ Keith E. Small, Textual Criticism and Qur'ān Manuscripts (Plymouth Inggris: Lexington Books, 2011).

${ }^{51}$ Lihat Fred Donner, "Review Textual Criticism and Qur'ān Manuscripts, karya Keith E. Small,”Journal of Near Eastern Studies 73, 1 (April 2014): 166-169.

${ }^{52}$ Tentang Manuskrip al-Qur'an San'ā' bisa dilihat di Behnam Sadegi dan Mohsen Goudarzi, "Șan'à' 1 and the Origins of the Qur'ān," Der Islam 87 (2011): 1-129. Sadeghi menulis: "Scholars have not yet been granted access to the microfilms that have been in the possession of Puin and Bothmer, nor has any author travelled to Șan'à' and published a study using the microfilms or manuscripts there." Sadeghi dan Goudarzi, "Șan‘à' 1 and the Origins of the Qur'ān," 11.

53 Tentang Corpus Coranicum Project lihat Oliver Leaman, "The Corpus Coranicum Project and the Issue of Novelty," Journal of Qur'anic Studies 15, 2 (2013): $142-148$. 
saat ini sedang mempersiapkan edisi kritis al-Qur'ān, yang hingga saat ini masih ditunggu hasilnya.

Karya Small Textual Criticism and Qur'ān Manuscript merupakan karya pertama dalam bentuk buku secara utuh yang menganalisa manuskrip-manukrip al-Qur'ān yang sebagian besarnya berasal dari masa awal Islam, dan juga perbedaan Qirā'àt. Dari kajian tersebut, Donner menyimpulkan bahwa:

\begin{abstract}
"Small's investigations show quite conclusively that many streams of evidence, expecially traces found in the erased lower layer of early palimpsest texts, lead to the conclusion that there was a very early attempt to establish a uniform consonantal text of the Qur'an from what was probably a wider and more varied group of related texts in early transmission. None of the extant variants seems to be the "Ur-Qur'an" ... or even the "Uthmanic recension," and from the evidence of the manuscripts and qira' $\bar{a} t$ literature it is not possible to reconstruct the supposed "UrQur'ān" of Muhammad's time .... After the creation of this standardized canonical text, earlier authoritative texts were suppressed, and all extant manuscripts -despite their numerous variants - seem to date to a time after this standard consonantal text was established." 54
\end{abstract}

Dari kajian Small juga dapat diambil kesimpulan bahwa pada saat penerimaan wahyu, Nabi secara lisan menyampaikan kepada para Sahabat yang kemudian menuliskannya dengan berbagai cara dan di berbagai bentuk. Kemudian Qur'ān awal yang banyak ini - yang bisa disebut sebagai teks alQur'ān yang otoritatif - diedit untuk membentuk teks al-Qur'ān yang kanonikal. Namun teks kanonikal ini masih belum berharakat sehingga masih menimbulkan masalah dalam pembacaannya. Pada saat itu (abad ketiga/kesembilan) terdapat paling tidak 80 macam qirāàt, lalu bersamaan dengan berlalunya waktu, berbagai cara dilakukan untuk mengurangi kemungkinan perbedaan dalam pembacaan al-Qur'ān. ${ }^{55}$

Demikianlah kesimpulan Small yang dalam beberapa hal membantah kesimpulan para sarjana Revisionis seperti Luling dan Wansbrough dan mendukung para sarjana Tradisionalis berdasarkan pada sumber dan manuskrip yang ada. Ini tidak berarti bahwa kesimpulan ini sudah final, karena sampel yang diambil oleh Small hanya surat 14 ayat 35-41 tentang "Ibrāhīm" berdasarkan pada 22 manuskrip al-Qur'ān awal dan juga literatur qirā'àt. Kajian

\footnotetext{
${ }^{54}$ Donner, "Review Textual Criticism,"168.

${ }^{55}$ Donner, "Review Textual Criticism,"168.
} 
lebih lanjut yang mencakup sampel yang lebih besar tentunya akan lebih meyakinkan dan konklusif.

Kajian selanjutnya yang berdasarkan pada manuskrip adalah karya Andrew J. Lane yang berjudul A Traditional Mu'tazilite Qur'ān Commentary: The Kashshāf of Jàr Allāh al-Zamakhsharī (d. 538/1144). ${ }^{56}$ Jika karya sebelumnya mengkaji manuskrip-manuskrip yang ada untuk melihat sejarah teks al-Qur'ān pada masa awal, maka karya ini mengkaji 250 manuskrip untuk melihat sejarah teks al-Kashshäf sejak tahun 528/1134 hingga saat ini. Salah satu yang menjadi fokus kajiannya adalah pernyataan al-Zamakhshari di awal bukunya "Al-hamdu li-Llāhi 1-ladhī khalaqa 1-Qur'ān” yang kemudian diubah menjadi “anzala l-Qur'ān.”

Yang menarik dari karya ini, sebagaimana yang disampaikan Bruce Fudge, adalah judulnya, yaitu tradisional Mu'tazilah, karena Lane ingin menyimpulkan bahwa al-Kashshäf, yang ditulis oleh seorang Mu'tazilah, tidak

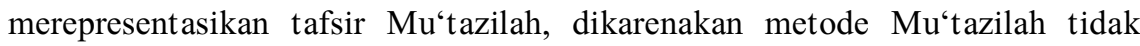
terlalu nampak dalam tafsir ini, begitu juga doktrin-doktrin $\mathrm{Mu}^{\text {'tazilah tidak }}$ terlalu banyak didiskusikan. ${ }^{57}$ Akan tetapi kesimpulan ini berbeda dengan kajian yang selama ini ada yang menegaskan ke-mu'tazilah-an al-Zamakhshari. Apalagi, Lane hanya mendasarkan kajiannya pada Q. 44 dan $54 !^{58}$

Karya selanjutnya yang menarik untuk dijadikan model kajian adalah karya Brannon M. Wheeler yang berjudul Moses in the Quran and Islamic Exegesis. ${ }^{59}$ Jika melihat dari judulnya, seakan-akan ini adalah merupakan tafsir mauḍu' 'i tentang Nabi Musa di dalam al-Qur'ān dan tafsir. Akan tetapi karya ini tidak hanya merujuk kepada ayat-ayat al-Qur'ān dan tafsir, ia juga merujuk kepada Bibel dan sumber-sumber non-Qur'an lainnya. Tesis utama dari karya ini adalah untuk membantah teori "borrowing" (peminjaman) atau "source" (sumber) al-Qur'ān dari Bibel dan sumber-sumber non Qur'ān. Sebaliknya Wheeler ingin menunjukkan bahwa al-Qur'ān dan tafsīr yang mempengaruhi sumber-sumber non Qur'ān.

Wheeler misalnya membandingkan Q. 18: 16-82 tentang nabi Musa dengan cerita Iskandar Agung dan Gilgamesh. Ia menunjukkan bahwa cerita

${ }^{56}$ Andrew J. Lane, A Traditional Mu'tazilite Qur'ān Commentary: The Kashshāf of Jār Allāh al-Zamakhsharì (d. 538/1144) (Leiden: Brill, 2006).

${ }^{57}$ Bruce Fudge, "Review of $A$ Traditional Mu'tazilite Qur'ān Commentary: The Kashshāf Jār Alläh al-Zamakhsharì (d. 538/1144) ," Journal of Qur'anic Studies 8, 2 (2006): 131-134.

${ }^{58}$ Fudge, "Review of $A$ Traditional Mu'tazilite Qur'ān Commentary,"133.

${ }^{59}$ Brannon M. Wheeler, Moses in the Quran and Islamic Exegesis (London: RoutledgeCurzon, 2002). 
tentang Iskandar Agung diambil sebagiannya dari tafsir al-Qur'ān tentang ayat tersebut, dan juga tentang Dhū 'l-Qarnayn. Begitu juga, Wheeler membantah kajian sarjana yang melihat Q. 18:60-82 bersumber dari cerita Hebrew tentang Rabbi Joshua b. Levi dan Elijah. Bagi Wheeler, cerita tersebut merupakan kelanjutan dari cerita di al-Qur'ān dan tafsīr dan bukan sebelum adanya alQur'ān dan tafsīr.

Sebagaimana yang ditunjukkan M.O. Klar, ${ }^{60}$ karya ini tidak hanya merujuk kepada al-Qur'ān, tafsīr, hạāth, qiṣas al-anbiyā', tapi juga ke Injil, Talmud, Midrash, Peshițta, Targums Nebi'im dan lain-lain, serta karya para sarjana modern tentang kisah-kisah Musa, Iskandar Agung dan Gilgamesh. Dengan demikian, karya ini tidak hanya menarik untuk pengkaji Islam tapi juga pengkaji Yahudi pada masa awal dan pertengahan.

Reynolds dalam karyanya The Qur'an and Its Biblical Subtext ${ }^{61}$ juga mempromosikan metode penafsiran al-Qur'an dengan mengkontekstualisasikan al-Qur'an dengan "Biblical subtext" nya, yaitu membaca al-Qur'an dengan merujuk kepada tradisi Bibel dan juga tradisi paska Bibel. Lagi-lagi, metode ini bukan untuk menunjukkan keterpengaruhan al-Qur'ān dari Bibel, akan tetapi untuk menggunakan tradisi Bibel dalam penafsiran ayat al-Qur'ān. Hal ini dilakukan untuk menunjukkan bahwa penafsiran al-Qur'an dengan Biblical subtext memberikan pemaknaan yang lain, yang kadang-kadang literatur tafsir tidak menjawabnya. Ini tentunya menuntut keilmuan lebih tidak hanya literature tafsir namun juga tradisi-tradisi Bibel.

Walid Saleh mengkaji tradisi tafsir masa klasik berjudul The Formation of the Classical Tafsir Tradition: The Qur'ān Commentary of al-Tha 'labì (d. 427/1035). ${ }^{62}$ Saleh merupakan salah satu sarjana Muslim yang aktif menulis kajian al-Qur'ān di Barat dan saat ini mengajar di University of Toronto, Kanada. Saleh mengkaji karya al-Tha'labī berjudul al-Kashf wa al-Bayān 'an Tafsìir al-Qur'ān yang masih berupa manuskrip, dan juga meletakkan karya ini dalam "genealogical tradition" tafsìr al-Qur'ān. Salah satu yang ingin dibuktikan Saleh adalah bahwa sebenarnya, dibandingkan dengan karya tafsir al-Ṭabari, karya-karya Nishapuri School of Qur'ān commentary, yang terdiri dari karya al-Tha'labi, gurunya al-Ḥasan ibn Muhammad ibn Habīb, dan

${ }^{60}$ M.O. Klar, "Review Moses in the Quran and Islamic Exegesis," Journal of Qur'anic Studies 5, 2 (2003): 121-125.

${ }^{61}$ Reynolds, The Qur'an and Its Biblical Subtext (New York: Routledge, 2010). Lihat Neuwirth "Review The Qur'an and Its Biblical Subtext," di Journal of Qur'anic Studies 14, 1 (2012): 131-166.

${ }^{62}$ Walid Saleh, The Formation of the Classical Tafsìr Tradition: The Qur'ān Commentary of al-Tha 'labi (d. 427/1035) (Leiden: Brill, 2004). 
muridnya al-Wahidi, lebih dominan dan berpengaruh terhadap literatur tafsir di masa setelahnya. Yang menarik lagi dari kajiannya adalah pernyataannya bahwa pembagian kategori tafsir menjadi tafsir bi al-ma'thūr dan tafsir bi al-ra'y adalah pembagian yang ideologis "ideological division." Bahkan kebanyakan tafsìr bi al-ma'thür masuk kategori tafsìr bi al-ra'y. ${ }^{63}$

Saleh membagi bukunya ke dalam beberapa bab. Bab intinya dimulia di Bab Ketiga ketika membahas struktur tafsīr al-Tha'labi dan sumbernya, yang membahas teori interpretasinya dan penafsirannya. Selanjutnya di Bab Keempat, ia membahas posisi tafsīir al-Tha'labi dalam literatur tafsìr yang ada. Bab Kelima dan Keenam membahas berbagai penafsiran dan tendensi penafsiran, seperti mistisisme, polemic politik dan doktrin dalam tafsir alTha'labi. Bab Ketujuh membahas resepsi dan respon terhadap tafsir al-Tha'labi.

Buku Saleh ini diterbitkan Penerbit Brill dalam "Texts and Studies of the Qur'ān” Series, dengan editornya Gerhard Bowering dan Jane D. McAuliffe. Karya Saleh merupakan karya pertama dalam Series ini, sementara hingga saat ini sudah menerbitkan hingga Series yang kesepuluh. ${ }^{64}$ Penerbit dan Institusi lain juga memiliki "Studies on the Qur'an series," seperti the Institute of Ismaili Studies, bekerjasama dengan Oxford University Press, memiliki Qur'anic Studies Series, yang hingga saat ini sejak tahun 2004 telah menerbitkan 14 karya. ${ }^{65}$ Routledge mempunyai Routledge Studies in the Qur'ān dengan editor Andrew Rippin dan Walid Saleh dan sudah menerbitkan 15 karya. ${ }^{66}$ Dan masih banyak lagi, yang tidak mungkin untuk saat ini, dikaji semuanya. Cukuplah untuk saat ini, tulisan ini menyatakan begitu kayanya kajian al-Qur'ān dan tafsīi di Barat. Masing-masing penerbit berlomba-lomba dalam menerbitkan karya-karya sarjana terkait dengan kajian al-Qur'ān dan tafsīr.

\section{Penutup}

Tulisan ini tidak bermaksud untuk membahas seluruh karya sarjana Barat yang terbit dalam bahasa Inggris. Tujuan utama dari tulisan ini adalah untuk menunjukkan kekayaan kesarjanaan Barat terhadap kajian al-Qur'ān dan tafsìr. Dalam pembahasan di atas, dapat dilihat perbedaan yang mencolok antara sarjana revisionis dengan sarjana tradisionalis, serta perkembangan kajian alQur'ān dan tafsīr yang tidak lagi (hanya) mengkaji sumber dan pengaruh luar

\footnotetext{
${ }^{63}$ Saleh, The Formation of the Classical Tafsir Tradition, 16.

${ }^{64}$ Lihat judul-judulnya di http://www.brill.com/publications/texts-and-studiesqur

65 Lihat judul-judulnya di https://global.oup.com/academic/content/series/q/quranic-studies-series-qss/?cc=au\&lang=en \&

${ }^{66}$ Lihat https://www.routledge.com/series/SE0482
} 
terhadap al-Qur'ān dan tafsīr, akantetapi hubungan intertekstual antara alQur'ān, tafsīr dan sumber-sumber lainnya.

Kajian di Barat didasari oleh kajian kritis akademis dan didukung pendekatan dan metodologi yang kaya. Tema-tema yang dikaji juga sangat beragam. Sudah selayaknya kesarjanaan Indonesia terhadap kajian al-Qur'ān dan tafsīr ikut meramaikan dan memperkaya kesarjanaan al-Qur'ān dan tafsìr. Semoga ...

\section{Daftar Pustaka}

Arkoun, M. "Contemporary Critical Practices and the Qur'ān," Encyclopaedia of the Qur'ān. Ed. Jane D. McAuliffe. Leiden: Brill, 2001. 1: 412-430.

Berg, Herbert. "The Implications of, and Opposition to, the Methods and Theories of John Wansbrough." Method \& Theory in the Study of Religion 9, 1 (1997): 3-22.

Donner, Fred. "Review Textual Criticism and Qur'ān Manuscripts, karya Keith E. Small.” Journal of Near Eastern Studies 73, 1 (April 2014): 166-169.

Fudge, Bruce. "Review of A Traditional Mu'tazilite Qur'ān Commentary: The Kashshāf Jār Allāh al-Zamakhsharī (d. 538/1144)." Journal of Qur'anic Studies 8, 2 (2006): 131-134.

Iqbal, Muzaffar. 'The Qur'ān, Orientalism, and The Encyclopaedia of the Qur'ān'. Journal of Qur'ānic Research and Studies 3:5 (2008), 11. The article is available at http://www.cis-ca.org/muzaffar/EQ-Rev.pdf . "Integrated Encyclopedia of the Qur'ān: Raison d'etre \& Project Summary." Islam \& Science 8, 1 (Summer 2010): 33-47.

Journal of Qur'anic Studies. "Planning Begins for Encyclopaedia of the Qur'an: Supplement." Journal of Qur'anic Studies 15, 2 (2013): 140-141.

Karimi-Nia, Morteza. "Contemporary Qur'anic Studies in Iran and its Relationship with Qur'ānic Studies in the West." Journal of Qur'anic Studies 14.1 (2012): 45-72.

Keeler, Annabel. Sufi Hermeneutics: The Qur'an Commentary of Rashid al-Din Maybudi. London: Institute of Ismaili Studies and Oxford University Press, 2006.

Klar, M.O. "Review Moses in the Quran and Islamic Exegesis." Journal of Qur'anic Studies 5, 2 (2003): 121-125.

Koc, Mehmet Akif. “The Influence of Western Qur'anic Scholarship on Turkey.” Journal of Qur'anic Studies 14.1 (2012): 9-44. 
Lane, Andrew J. A Traditional Mu'tazilite Qur'ān Commentary: The Kashshāf of Jār Allāh al-Zamakhsharī (d. 538/1144). Leiden: Brill, 2006.

Leaman, Oliver. "The Corpus Coranicum Project and the Issue of Novelty." Journal of Qur'anic Studies 15, 2 (2013): 142-148.

Leaman, Oliver. The Qur'an: An Encyclopedia. London: Routledge, 2006.

Madigan, Daniel. "Foreword." The Qur'ān in Its Historical Context, New York: Routledge, 2008.

McAuliffe, Jane D. Qur'anic Christians: an Analysis of Classical and Modern Exegesis. Cambridge; New York: Cambridge University Press, 1991.

. (Ed.) Cambridge Companion to the Qur'än. Cambridge, 2006.

. (Main Editor). Encyclopaedia of the Qur'ān. Leiden: Brill, 2001-2006, 5 jilid + indeks.

, Barry D. Walfish dan Joseph W. Goering (Eds.). With Reference for the Word: Medieval Scriptural Exegesis in Judaism, Christianity, and Islam. Oxford: Oxford University Press, 2003.

Meuleman, Johan. "South-East Asian Islam and the Globalization Process." Dalam Islam in the Era of Globalization: Muslim Attitudes towards Modernity and Identity. Ed. Johan Meuleman. London: RoutledgeCurzon, 2002, 13-29.

Neuwirth, Angelika. "Qur'anic Studies and Historical-Critical Philology: The Qur'an's Staging, Penetrating, and Eclipsing of Biblical Tradition.” https://iqsaweb.wordpress.com/publications/papers/.

-------. "Review The Qur'an and Its Biblical Subtext." Journal of Qur'anic Studies 14, 1 (2012): 131-166.

-------. Scripture, Poetry and the Making of a Community: Reading the Qur'an as a Literary Text. London: Oxford University Press in association with the Institute of Ismaili Studies, 2014.

-------, Nicolai Sinai, dan Michael Marx (Eds.). The Qur'an in Context: Historical and Literary Investigations into the Qur'anic Milieu. Leiden: Brill, 2010.

Rahman, Yusuf. “The Indonesian Muslim Responses to the Outsiders' Studies of the Qur'an and Tafsir." Makalah Konferensi Internasional "New Trends in Qur'anic Studies" yang diselenggarakan UIN Sunan Kalijaga Yogyakarta dan International Qur'anic Studies Association (IQSA) di Yogyakarta, 4-6 Agustus 2015. Belum diterbitkan.

. "Tren Kajian Al-Qur'an di Dunia Barat.” Jurnal Studia Insania 1, 1 (April 2013): 1-8. 
Reynolds, Gabriel Said. The Qur'an and Its Biblical Subtext. New York: Routledge, 2010.

-------. "Introduction: the Golden Age of Qur'annic Studies?." Dalam New Perspectives on the Qur'an: the Qur'an in Its Historical Context 2. Ed. Gabriel Said Reynolds. New York: Routledge, 2011, 1-21.

-------. “Introduction.” Dalam The Qur'ān in Its Historical Context. Ed. Gabriel Said Reynolds. New York: Routledge, 2008

-------. (Ed.). New Perspectives on the Qur'ān: The Qur'ān in Its Historical Context 2. New York: Routledge, 2011.

(Ed.) The Qur'ān in Its Historical Context. New York: Routledge, 2008.

Rippin, Andrew. The Qur'an and Its Interpretative Tradition. Burlington, Vermont: Ashgate Publishing Company, 2001.

"Angelika Neuwirth and Philology: A Response to the Keynote Lecture." https://iqsaweb.wordpress.com/publications/papers/.

------. "Literary Analysis of Qur'ān, Tafsir and Sïra: the Methodologies of John Wansbrough.” Di Approaches to Islam in Religious Studies. Ed. R. C. Martin. Tucson: University of Arizona Press, 1985, 151-163, 227-232. . "Quranic Studies, part IV: Some Methodological Notes." Method and Theory in the Study of Religion IX (1997): 39-46.

--------. "The Reception of Euro-American Scholarship on the Qur'ann and Tafsīr: An Overview." Journal of Qur'anic Studies 14.1 (2012): 1-8.

-------. "Review of The Koran, ed. Colin Turner." Bulletin of the School of Oriental and African Studies 69, 1 (February 2006): 141-142.

" "Review of The Qur'an in Context." Journal of the American Oriental Society 131, 3 (2011): 470-473.

-------. (Ed.). The Qur'ān: Formative Interpretation. Burlington, Vermont: Ashgate Publishing Company, 1999.

-------. (Ed.). The Qur'ān: Style and Contents. Brookfield, Vermont: Ashgate Publishing Company, 2001.

-------. (Ed.) The Blackwell Companion to the Qur'an. Oxford: Blackwell Publishing, 2006.

Sadegi, Behnam dan Mohsen Goudarzi. "Șan‘à' 1 and the Origins of the Qur'ān.” Der Islam 87 (2011): 1-129.

Saleh, Walid. The Formation of the Classical Tafsir Tradition: The Qur'ān Commentary of al-Tha 'labi (d. 427/1035). Leiden: Brill, 2004.

Shah, Mustafa. (Ed.). Tafsir: Interpreting the Qur'an. London: Routledge, 2013. ."Review EQ volume 4, 5, Indices." Bulletin of the School of Oriental and African Studies 71, 2 (2008): 365-366. 
Sinai, Nicolai dan A. Neuwirth. "Introduction." Dalam The Qur'an in Context: Historical and Literary Investigations into the Qur'anic Milieu. Leiden: Brill, 2010.

Small, Keith E. Textual Criticism and Qur'ān Manuscripts. Plymouth Inggris: Lexington Books, 2011.

Turner, Colin (Ed.) The Koran: Critical Concepts in Islamic Studies. London: RoutledgeCurzon, 2004.

Wheeler, Brannon M. Moses in the Quran and Islamic Exegesis. London: RoutledgeCurzon, 2002.

Wild, Stefan. "Review of EQ." Die Welt des Islams 43, 2 (2003): 294-297. 